\title{
Pengaruh Kepemimpinan Kepala Sekolah dan Budaya Organisasi terhadap Komitmen Guru dalam Melaksanakan Tugas
}

\author{
Asma'ul Husnah" ${ }^{*}$, Edi Harapan' ${ }^{2}$ Rohana $^{2}$ \\ ${ }^{1}$ SMA Negeri 1 Sekayu, Musi Banyuasin, Sumatera Selatan, Indonesia \\ ${ }^{2}$ Universitas PGRI Palembang, Palembang, Sumatera Selatan, Indonesia \\ Corresponding author: Asma'ul Husnah (e-mail: ahusnah901@ gmail.com $)$
}

\begin{abstract}
Abstrak: Penelitian ini bertujuan untuk mengkaji kepemimpinan kepala sekolah dan budaya organisasi terhadap komitmen guru dalam melaksanakan tugas. Penelitian ini dilakukan pada sekolah menengah atas negeri (SMAN) di Kota Sekayu, Provinsi Sumatera Selatan. Penelitian ini menggunakan pendekatan kuantitatif. Sampel penelitian yaitu 115 guru di lima SMA Negeri di Kota Sekayu yang dipilih dengan teknik simple random sampling. Teknik pengumpulan data dilakukan dengan penyebaran angket. Data yang terkumpul dianalisis secara kuantitatif dengan menggunakan program SPSS 25 for windows yang dilakukan dalam tiga tahap, yaitu analisis deskriptif, analisis asosiatif, dan analisis koefisien determinan. Hasil penelitian menunjukkan bahwa kepemimpinan kepala sekolah berpengaruh signifikan terhadap komitmen guru dengan nilai koef isien sebesar 0,438 , budaya organisasi berpengaruh signif ikan terhadap komitmen guru dengan nilai koefisien sebesar 0,506, dan kepemimpinan kepala sekolah dan budaya organisasi secara bersama-sama (simultan) berpengaruh signifikan terhadap komitmen guru dalam melaksanakan tugas dengan nilai koefisien sebesar 0,584 . Hasil penelitian ini diharapkan mampu mendorong peningkatan kepemimpinan kepala sekolah dan pengembangan budaya organisasi guna mengoptimalkan komitmen guru dalam melaksanakan tugas.
\end{abstract}

Kata Kunci: kepemimpinan, budaya organisasi, komitmen guru

\section{The Influence of School Leadership and School Organizational Culture on Teachers' Commitment in Implementing Tasks}

\begin{abstract}
This study examined the principal leadership and the organizational culture to the teachers' commitment to carry out their tasks. This research was conducted at public high schools (SMAN) in Sekayu City, South Sumatra Province. This research use d a quantitative approach. The research sample was 115 teachers at five public high schools in Sekayu city, selected using a simple random sampling technique. The data collection technique applied was survey using a questionnaire. The collected data was analyzed quantitatively using SPSS 25 for the windows program conducted in three stages: descriptive analysis, associative analysis, and determinant coefficient analysis. The results showed that the principal leadership had a significant effect on teacher commitment with a coefficient value of 0.438 , organizational culture significantly influenced teacher commitment with a coefficient value of 0.506, and the principal leadership and organizational culture simultaneously influenced the teacher's commitment to carry out their tasks with a coefficient value of 0.584. This study suggests that
\end{abstract}


it is necessary to develop principal leadership and organizational culture in order to increase teachers' commitment to carrying their tasks.

Keywords: leadership, organizational culture, teachers' commitment to work

\section{PENDAHULUAN}

Tugas pokok seorang guru yaitu mengajar dan bertanggung jawab atas terlaksananya proses pembelajaran mulai dari merencanakan, melaksanakan, dan mengevaluasi hasil belajar (Usman, 2017). Undang-undang Nomor 14 tahun 2005 mengamanatkan kepada guru selaku pendidik profesional dengan tugas utama mendidik, mengajar, membimbing, mengarahkan, melatih, menilai, dan mengevaluasi peserta didik pada jalur formal pendidikan dasar dan pendidikan menengah. Menurut Jannah (2014), tugas tersebut akan terlaksana dengan baik jika guru memiliki komitmen yang tinggi untuk melaksanakan semua tugas yang dibebankan kepadanya. Mathis dan Jackson (2011) berpendapat bahwa komitmen dipandang sebagai suatu orientasi nilai terhadap organisasi yang menunjukkan individu sangat memikirkan dan mengutamakan pekerjaan dan organisasinya. Individu akan berusaha memberikan segala usaha yang dimilikinya dalam rangka membantu organisasi mencapai tujuannya.

Kehadiran guru profesional di sekolah menduduki peran sangat strategis. Koestoero dan Hadisucipto (1998) mengatakan "sehebat apapun fasilitas yang tersedia, proses belajar mengajar tidak akan berjalan baik tanpa adanya guru-guru yang profesional". Menyadari pentingnya peran guru, setiap guru dituntut memiliki komitmen tinggi dalam menjalani profesi yang disandangnya. Guru yang memiliki komitmen tinggi tidak hanya profesional dalam mengajar di kelas tetapi juga memegang teguh kompetensi yang dimilikinya. Guru yang berkomitmen pada tugas profesinya akan berusaha meningkatkan kemampuan diri melalui kegiatan workshop dan pelatihan melanjutkan pendidikannya ke jenjang yang lebih tinggi, mengurus jenjang kepangkatannya, sanggup bekerja keras, bekerja tuntas, dan bekerja ikhlas. Komitmen guru penting dibahas sebagai bagian dari upaya menghasilkan guru professional (Zahrana, 2017).

Nawawi (2003) berpendapat "komitmen guru dapat tumbuh dari diri masing-masing atau dibangun oleh kepala sekolah”. Hal ini dipertegas oleh Flippo (2012), Darmanto, \& Muharto (2014) yang menyimpulkan bahwa pimpinan berpengaruh langsung terhadap komitmen staf pada organisasinya. Colquitt, LePine, \& Wesson, (2009) juga berpandangan bahwa komitmen dapat dipengaruhi oleh faktor di luar individu seperti budaya organisasi, iklim organisasi, kepuasan kerja, kepemimpinan, dan kerja sama kelompok. Dari berbagai faktor 
tersebut, dua variabel yang besar pengaruhnya terhadap komitmen guru yaitu kepemimpinan kepala sekolah dan budaya organisasi.

Kepemimpinan menurut Ekosiswoyo (2007) adalah kemampuan dan kesiapan seseorang untuk mempengaruhi, membimbing, mengarahkan dan menggerakkan orang lain agar mau berbuat sesuatu dengan rasa tanggung jawab untuk mencapai tujuan yang telah ditetapkan bersama. Kepala sekolah yang efektif adalah kepala sekolah yang mampu mempengaruhi guru agar mau melaksanakan semua tugas yang dibebankan kepadanya sehingga visi dan misi sekolah dapat dicapai. Kepala sekolah yang handal selain mampu memimpin guru-guru dan tenaga kependidikan lainnya, juga mampu menjadi manajer, administrator, supervisor, motivator, innovator, dan entrepreneur. Kemampuan kepala sekolah melaksanakan berbagai fungsi tersebut diperkirakan mampu meningkatkan komitmen guru dalam melaksanakan tugas.

Selain kepemimpinan kepala sekolah, komitmen guru dalam melaksanakan tugas juga dipengaruhi oleh budaya organisasi sekolah. Sutrisno dalam Muis, Jufrizen, \& Fahmi (2018) berpendapat bahwa budaya organisasi merupakan perangkat sistem nilai-nilai (values) atau norma-norma (beliefs), asumsi-asumsi (asssumptions), yang telah lama berlaku, yang disepakati dan diikuti oleh anggota organisasi. Budaya ini menjadi pedoman perilaku dan pemecahan masalah-masalah organisasi. Penerapan konsep budaya organisasi di sekolah berfungsi untuk mengembangkan, melestarikan, dan mewariskan nilai-nilai budaya kepada para guru dan siswanya. Budaya organisasi merupakan cerminan kerangka pencapaian mutu pendidikan di sekolah. Lembaga pendidikan yang memiliki budaya organisasi yang baik tercermin dari pola-pola pembuatan kebijakan, pengambilan keputusan, musyawarah dengan semua stakeholder yang ada di sekolah, etika dan kehormatan guru, dan lain sebagainya. Berdasarkan uraian tersebut, penelitian ini bertujuan untuk menguji dua variabel yang diperkirakan sangat dominan mempengaruhi komitmen guru dalam melaksanakan tugas, yaitu kepemimpinan kepala sekolah dan budaya organisasi sekolah.

\section{METODE PENELITIAN}

Penelitian ini dilaksanakan di lima sekolah menengah atas negeri (SMAN) yang ada di Kota Sekayu, Provinsi Sumatera Selatan. Penelitian dilaksanakan sejak bulan Juli hingga Desember 2020. Metode penelitian yang digunakan adalah metode kuantitatif. Populasi penelitian ini meliputi semua guru yang mengajar di SMAN yang ada di Kota Sekayu yang berjumlah 162 
orang. Sampel ditetapkan sebanyak 115 responden yang diambil dengan teknik acak sederhana (simple random sampling) menggunakan Rumus Taro Yaname dan Slovin, dengan presisi 5\%.

Teknik pengumpulan data dilakukan dengan penyebaran angket kepada responden terpilih. Pengukuran masing-masing variabel menggunakan skala Likert. Sebelum menganalisis data, langkah penelitian dimulai dari penyusunan angket, pengukuran tingkat validitas dan reabilitas instrumen, melakukan uji persyaratan analisis, dan pembuktian hipotesis. Hasil uji coba instrumen pada ketiga variabel menunjukkan bahwa semua butir pernyataan valid dan reliabel. Ini berarti semua butir pernyataan di setiap variabel dapat digunakan dalam penelitian ini. Selain itu hasil uji persyaratan analisis menunjukkan semua variabel memenuhi unsur normalitas, linieritas, multikolinieritas, dan autokorelasi. Dengan demikian, semua data dari masing-masing variabel telah memenuhi syarat untuk dianalisis menggunakan statistik parametrik.

Setelah data terkumpul, data dianalisis dengan bantuan program SPSS for windows versi 25 yang dilakukan dalam tiga tahapan, yaitu (1) analisis deskriptif, (2) analisis asosiatif, dan (3) analisis koefisien determinan. Analisis deskriptif bertujuan untuk menganalisis masingmasing variabel yang diteliti, yaitu analisis variabel komitmen guru melaksanakan tugas, analisis variabel kepemimpinan kepala sekolah, dan analisis variabel budaya organisasi sekolah. Analisis asosiatif bertujuan untuk menganalisis masing-masing hubungan variabel yang diteliti. Pada analisis asosiatif ini dilakukan uji hubungan parsial dan uji hubungan simultan. Analisis koefisien determinan bertujuan untuk menguji sebesar-besar pengaruh variabel independen (kepemimpinan kepala sekolah dan budaya organisasi sekolah) terhadap variabel dependen (komitmen guru melaksanakan tugas).

\section{HASIL}

\subsection{Pengaruh kepemimpinan kepala sekolah terhadap komitmen guru dalam melaksanakan tugas}

Hipotesis pertama yang akan dibuktikan dalam penelitian ini adalah kepemimpinan kepala sekolah berpengaruh signifikan terhadap komitmen guru melaksanakan tugas. Hasil penghitungannya dapat dilihat dari output pada tabel 1 berikut.

Tabel 1. Ha sil a nalisis koefisien determinasi $X_{l}-Y$

\begin{tabular}{lrrrr}
\hline \multicolumn{5}{c}{ Model Summary $^{\mathbf{b}}$} \\
Model & $\mathbf{R}$ & R Square & Adjusted R Square & Std. Error of the Estimate \\
\hline 1 &, $662^{\mathrm{a}}$ &, 438 &, 433 & 4,989 \\
\hline $\begin{array}{l}\text { a. Predictors: (Constant), Variabel_X1 } \\
\text { b. Dependent Variabel: Variabel_Y }\end{array}$ & &
\end{tabular}


Berdasarkan tabel 1, $R$ memperoleh nilai sebesar 0,662 a Artinya, terdapat korelasi antara kepemimpinan kepala sekolah $\left(X_{1}\right)$ dengan komitmen guru melaksanakan tugas $(Y)$ sebesar 0,662 a. Hal ini menunjukkan bahwa hubungan kepemimpinan kepala sekolah dengan komitmen guru melaksanakan tugas termasuk dalam kategori "tinggi" karena berada pada rentang 0.600 - 0.799, sesuai dengan pedoman interpretasi koefisien korelasi (Sugiyono, 2014). Lebih lanjut, pengaruh kepemimpinan kepala sekolah terhadap komitmen guru melaksanakan tugas mendapatkan nilai 0,438, termasuk dalam kategori "tinggi" karena $\geq 0.30$ (Suwarno, 1988). Dengan demikian, komitmen guru melaksanakan tugas dipengaruhi kepemimpinan kepala sekolah sebesar 43,8\%.

Selanjutnya, untuk mengetahui apakah kepemimpinan kepala sekolah berpengaruh signifikan terhadap komitmen guru melaksanakan tugas, perlu dilakukan uji t atau uji signifikansi. Hasil analisis uji signifikansi kepemimpinan kepala sekolah dengan komitmen guru melaksanakan tugas disajikan dalam tabel 2 berikut.

Tabel2. Coefficients ${ }^{\mathrm{a}}$ uji $t$ variabel $X_{I}-Y$

\begin{tabular}{llrrrrr}
\hline \multirow{2}{*}{ Model } & \multicolumn{2}{c}{ Unstandardized Coefficients } & $\begin{array}{c}\text { Standardized } \\
\text { Coefficients }\end{array}$ & \multirow{2}{*}{ T } & Sig. \\
\cline { 2 - 5 } & \multicolumn{1}{c}{ B } & Std. Error & Beta & & \\
\hline 1 & (Constant) & 25,599 & 5,513 & & 4,643 &, 000 \\
& Variabel_X1 &, 617 &, 066 &, 662 & 9,383 &, 000 \\
\hline
\end{tabular}

a.Dependent Variabel: Variabel_Y

Pada tabel 2 di atas diperoleh nilai $t_{\text {hitung }}$ sebesar 9,383 dengan taraf signifikan 0.000. Nilai ini selanjutnya dibandingkan dengan nilai $t_{\text {Tabel }}$ sebesar 1,980. Nilai $t_{\text {Tabel }}$ ini dapat dilihat pada tabel statistik dengan signifikansi $0,05: 2=0,025$ pada derajat kebebasan $(d f)=n-k$ atau $115-2=113$. Hasilnya yaitu nilai $t_{\text {hitung }} 9,383>$ nilai $t_{\text {Tabel }} 1,980$ dan nilai signifikansi $0,000<0,005$. Ini berarti $\mathrm{H}_{\mathrm{o} 1}$ ditolak dan $\mathrm{H}_{\mathrm{a} 1}$ diterima, kepemimpinan kepala sekolah pada SMAN di Sekayu berpengaruh signifikan terhadap komitmen guru-guru di sekolah tersebut dalam melaksanakan tugas.

\subsection{Pengaruh budaya organisasi sekolah terhadap komitmen guru dalam melaksanakan tugas}

Hipotesis kedua yang diuji dalam penelitian ini adalah buday a organisasi berpengaruh terhadap komitmen guru melaksanakan tugas. Hasil penghitunganny a dapat dilihat dari ouputpada tabel berikut. 
Tabel3. Ha sil analisis koefisien determinasi $X_{2}-Y$

\begin{tabular}{lrrrr}
\hline \multicolumn{4}{c}{ Model Summary } \\
Model & R & R Square & Adjusted R Square & Std. Error of the Estimate \\
\hline 1 &, $712^{\text {a }}$ &, 506 &, 502 & 4,676 \\
\hline a.Predictors: (Constant), Variabel_X1 & & \\
b. Dependent Variabel: Variabel_Y &
\end{tabular}

Berdasarkan tabel 3 di atas dapat dilihat bahwa nilai $R$ untuk budaya organisasi sebesar $0,712^{\mathrm{a}}$. Ini berarti ada korelasi antara budaya organisasi $\left(X_{2}\right)$ dengan komitmen guru melaksanakan tugas $(Y)$. Hubungan inidalam kategori “tinggi” karena berada pada rentang 0,60 - 0,799. Hal ini didasarkan pada pedoman interpretasi koefisien korelasi (Sugiyono, 2014). Lebih lanjut, pengujian pengaruh variabel budaya organisasi $\left(X_{2}\right)$ terhadap komitmen guru melaksanakan tugas $(Y)$ didasarkan padakoefisien determinasi $\left(R^{2}\right)$. Berdasarkan output Tabel Model Summary di atas diperoleh nilai $R^{2}$ sebesar 0,506 yang menunjukkan pengaruh yang “tinggi” karena $\geq 0.30$ (Suwarno, 1988). Dengan demikian, variabel komitmen guru melaksanakan tugas mendapat pengaruh dari budaya organisasi sebesar 50,6\%.

Uji $t$ dilakukan untuk menguji signifikansi korelasi secara parsial antara variabel bebas kedua dengan variabel terikat, apakah berkorelasi signifikan atau tidak, pada $\alpha 0,05$. Hasil analisis uji signifikansi korelasi budaya organisasi dengan komitmen guru melaksanakan tugas disajikan dalam tabel 4 coefficiens berikut

Tabel4. Coefficients ${ }^{\mathrm{a}}$ uji $t$ variabel $X_{2}-Y$

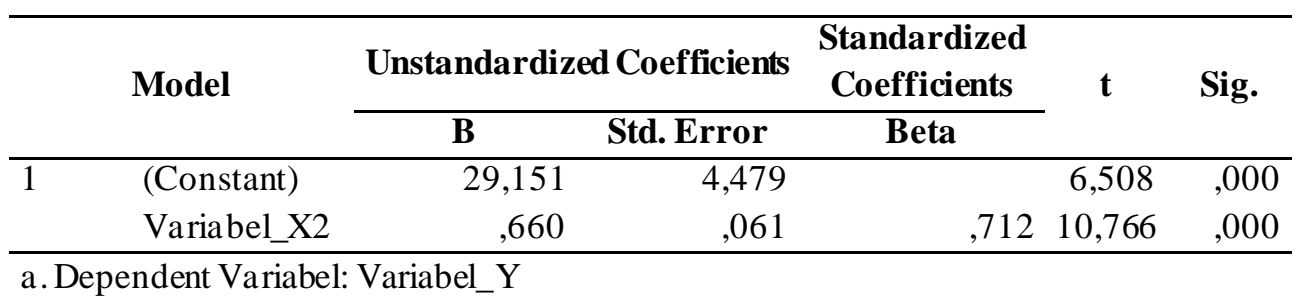

Pada tabel 4, nilai $t_{\text {hitung }}$ sebesar 10,766 dengan taraf signifikan 0,000 dibandingkan dengan nilai $t_{\text {Tabel }}$ sebesar 1,980. Nilai $t_{\text {Tabel }}$ pada tabel statistik dengan signifikansi 0,05:2= 0,025 dengan derajat kebebasan $(d f)=n-k$ atau $115-2=113$ adalah 1.980. Dengan demikian, nilai $t_{\text {hitung }} 10,766>t_{\text {Tabel }} 1,980$ dan nilai signifikansi $0,000<0,005$, yang berarti $\mathrm{H}_{\mathrm{o} 2}$ ditolak dan $\mathrm{H}_{\mathrm{a} 2}$ diterima. Kesimpulannya yaitu komitmen guru-guru SMAN di Kota Sekayu dalam melaksanakan tugas mendapat pengaruh signifikan dari budaya organisasi sekolah. 


\subsection{Pengaruh kepemimpinan kepala sekolah dan budaya organisasi terhadap komitmen guru dalam melaksanakan tugas}

Hipotesis ketiga yang diuji dalam penelitian ini yaitu kepemimpinan kepala sekolah dan budaya organisasi secara bersama-sama (simultan) berpengaruh terhadap komitmen guru melaksanakan tugas. Hasil penghitunganny a dapat dilihat dari output pada tabel 5 berikut.

Tabel5. Ha sil Analisis Koefisien Determinasi $X_{1}$ dan $X_{2}-Y$

\begin{tabular}{lrrrr}
\hline & \multicolumn{3}{c}{ Model Summary } \\
Model & R & R Square & Adjusted R Square & Std. Error of the Estimate \\
\hline 1 & $.764^{\text {a }}$ & .584 & .576 & 4.313 \\
\hline a.Predictors: (Constant), Variabel_X1 & & \\
b. Dependent Variabel: Variabel_Y & &
\end{tabular}

Tabel 5 menujukkan nilai $R$ sebesar $0.764^{\text {a }}$ yang bermakna bahwa terdapat korelasi antara kepemimpinan kepala sekolah $\left(X_{1}\right)$ dan budaya organisasi $\left(X_{2}\right)$ terhadap nilai komitmen guru melaksanakan tugas $(Y)$ sebesar 0.764 a . Nilai ini juga menunjukkan kategori hubungan yang "tinggi" karena berada pada rentang 0.60-0.799 (Sugiyono, 2014).

Pengaruh variabel kepemimpinan kepala sekolah $\left(X_{1}\right)$ dan budaya organisasi $\left(X_{2}\right)$ terhadap komitmen guru melaksanakan tugas $(Y)$ dapat dilihat dari nilai determinasi $\left(R^{2}\right)$. Berdasarkan tabel 5 di atas, nilai $R^{2}$ sebesar 0,584 yang berarti termasuk dalam kategori "tinggi", karena berada $\geq 0,30$ (Suwarno, 1988). Dengan demikian, komitmen guru melaksanakan tugas mendapat pengaruh secara simultan dari kepemimpinan kepala sekolah dan budaya organisasi sebesar $58,4 \%$.

Langkah selanjutnya adalah melakukan uji Fyang bertujuan untuk menguji siginifkansi korelasi antara semua variabel bebas terhadap variabel terikat pada $\alpha 0,05$. Hasil analisis uji $F$ disajikan dalam Tabel 6 berikut ini.

Tabel6. ANOVA a uji $F$ variabel $X_{I}$ dan $X_{2}-Y$

\begin{tabular}{llrrrrr}
\hline Model & & Sum of Squares & df & Mean Square & F & Sig. \\
\hline 1 & Regression & 2920.942 & 2 & 1460.471 & 78.507 & $.000^{\mathrm{b}}$ \\
& Residual & 2083.545 & 112 & 18.603 & & \\
& Total & 5004.487 & 114 & & & \\
\hline
\end{tabular}

a.Dependent Variabel: Variabel_Y

b. Predictors: (Constant), Variabel_X2, Variabel_X1

Nilai $F_{\text {Tabel }}$ dapat dilihat pada tabel statistik dengan signifikansi 0,05:2 $2=0,025$ pada derajat kebebasan $(d f)=n-k$ atau $115-2=113$. Hasil yang diperoleh untuk $F_{\text {Tabel }}$ sebesar 3.09. Dengan demikian, $F_{\text {hitung }} 78.507>$ nilai $F_{\text {Tabel }} 3,09$ dan nilai signifikansi $0,000<0,025$ yang artinya $\mathrm{H}_{03}$ ditolak dan $\mathrm{H}_{\mathrm{a} 3}$ diterima. Kesimpulannya yaitu kepemimpinan kepala sekolah dan budaya organisasi berpengaruh signifikan terhadap komitmen guru melaksanakan tugas. 


\section{PEMBAHASAN}

\subsection{Pengaruh kepemimpinan kepala sekolah terhadap komitmen guru dalam melaksanakan tugas}

Hasil penelitian menunjukkan bahwa kepemimpinan kepala sekolah di seluruh SMAN di Kota Sekayu memiliki hubungan signifikan dengan komitmen guru dalam melaksanakan tugas. Hasil penelitian ini mendukung temuan penelitian sebelumnya yang dilakukan oleh Mawaddah, dkk. (2020) yang dilaksanakan di Kecamatan Tanjungraja Kabupaten Ogan Komering Ilir Provinsi Sumatera Selatan. Hasil penelitian menunjukkan bahwa kepemimpinan kepala sekolah berpengaruh terhadap kepuasan kerja guru. Kepuasaan kerja dapat terjadi karena adanya komitmen guru untuk melaksanakan tugas. Temuan ini juga menunjukkan bahwa fasilitas pembelajaran yang disediakan oleh kepala sekolah ikut mempengaruhi komitmen guru. Hasil penelitian Rosdina (2015), Aminuddin (2017), Syamsul (2017), dan Kosim (2017) menunjukkan hasil serupa. Kepemimpinan kepala sekolah berpengaruh positif secara signifikan terhadap kinerja guru.

Selanjutnya, temuan penelitian Muslim, dkk (2020) menyimpulkan bahwa kepemimpinan kepala sekolah meliputi cara berkomunikasi, pemberian motivasi, kemampuan memimpin, pengambilan keputusan, dan kekuasaan. Menurut Syaiful (2018), selain tanggung jawab, komitmen guru juga efektif untuk membentuk karakter siswa. Guru profesional akan bertanggung jawab membentuk karakter siswa dan menjalankan tujuan, visi, dan misi sekolah. Realisasi komitmen guru yang tinggi dan konsisten ditunjukkan melalui cara guru memberikan layanan dan kemampuan menyesuaikan diri dengan lingkungan sekolah. Strategi menumbuhkan komitmen guru dalam tugas pengajaran dapat dilakukan oleh kepala sekolah melalui pemberian penghargaan dan hukuman, pembiasaan, dan program kerja.

\subsection{Pengaruh budaya organisasi sekolah terhadap komitmen guru dalam melaksanakan tugas}

Hasil penelitian memperlihatkan bahwa budaya organisasi pada semua SMAN di Kota Sekayu berhubungan dan berpengaruh signifikan terhadap komitmen guru dalam melaksanakan tugas. Hasil penelitian ini sejalan dengan penelitian yang dilakukan oleh Jurman (2014) yang dilaksanakan di SMAN 1 Simeulue Timur Provinsi Banda Aceh. Hasil penelitiannya menemukan bahwa pembinaan budaya disiplin dalam meningkatkan kinerja guru SMA berorientasi pada aturan yang telah ditetapkan, baik peraturan perundang-undangan maupun peraturan sekolah. Pembinaan disiplin guru dilakukan secara bertahap atau berkala, mulai dari 
penentuan deskripsi pekerjaan, pendekatan yang persuasif, pengawasan proses pembelajaran dan pembimbingan tugas yang diberikan kepada guru, serta pemberian sanksi sesuai dengan tingkat pelanggaran.

Penelitian Yusuf (2017) juga menemukan tahapan pengembangan budaya organisasi yang relevan untuk diterapkan pada lembaga pendidikan. Konsep, fungsi, tipe dan pengembangan budaya organisasi terdiri dari open and participative culture, close and autocratic culture, pembentukan budaya organisasi, strategi memperkuat budaya organisasi yang terdiri dari (solidaritas mekanik dan solidaritas organik), serta strategi pengembangan budaya organisasi yang dilakukan secara berkesimbungan. Hal ini sangat tepat dijadikan sebagai acuan bagi setiap lembaga pendidikan dalam mencapai tujuan yang telah ditetapkan. Hasil penelitian ini menunjukkan budaya organisasi memiliki pengaruh terhadap komitmen guru dalam melaksanakan tugas. Komitmen yang tinggi dari seorang guru yang selalu setia dan terlibat aktif dalam lembaga pendidikan tempatnya bertugas ditunjukkan dengan keterikatannya pekerjaan dengan rasa tanggung jawab yang tinggi. Hal tersebut dipengaruhi oleh budaya organisasi yang berjalan di lembaga pendidikan tersebut.

Budaya organisasi setiap sekolah dipandang sebagai keunikan tersendiri dari setiap lembaga pendidikan. Sifat dan ciri budaya yang ditanamkan dalam organisasi sekolah akan berdampak pada layanan yang diberkan kepada warga sekolah dan masyarakat. Hasilobservasi menunjukkan tumbuh kembangnya budaya organisasi sekolah dipengaruhi oleh beberapa sumber, yaitu manajer/kepala sekolah, perilaku guru, dan lingkungan masyarakat di sekitar sekolah. Hal ini sejalan dengan pendapat Steers (1991) bahwa faktor-faktor yang mempengaruhi budaya organisasi adalah struktur tugas, imbalan, hukuman, sentralisasi keputusan, prestasi, tekanan pekerjaan, keamanan, ancaman, karakter, jabatan, pengakuan, dan layanan. Berbagai faktor tersebut dapat terjadi pada lembaga pendidikan.

\subsection{Pengaruh kepemimpinan kepala sekolah dan budaya organisasi secara simultan terhadap komitmen guru dalam melaksanakan tugas}

Hasil penelitian ini menunjukkan bahwa kepemimpinan kepala sekolah dan budaya organisasi sekolah secara simultan memberi pengaruh yang signifikan terhadap komitmen guru dalam melaksanakan tugas. Temuan ini sejalan dengan Colquitt, LePine, \& Wesson (2009) yang mengemukakan bahwa komitmen dapat dipengaruhi oleh budaya organisasi, kepuasan kerja, kepemimpinan, dan kerjasama kelompok. Selain kepemimpinan kepala sekolah dan budaya 
organisasi, terdapat variable-variabel lain yang dapat memberikan sumbangan kepada komitmen guru dalam melaksanakan tugas.

Menurut Noe, et al. (2013), komitmen merupakan tingkat yang tinggi pada diri seseorang yang merasa telah menyatukan dirinya dengan organisasi dan mau berusaha serta berbuat demi kepentingan organisasi tersebut. Pernyataan tersebut menyiratkan bahwa guru yang memiliki komitmen yang rendah sering kali hanya menghindar dari pekerjaan yang dibebankan terhadap mereka. Nawawi (2003) mengatakan bahwa komitmen guru juga dipengaruhi oleh kepala sekolah sebagai unsur pimpinan. Pendapat ini telah dibuktikan oleh beberapa penelitian terkait pengaruh kepemimpinan kepala sekolah terhadap komitmen guru. Flippo (2012) menyimpulkan bahwa kepemimpinan kepala sekolah memberikan pengaruh langsung terhadap komitmen guru. Kesimpulan penelitian tersebut menyatakan bahwa semakin baik kepemimpinan kepala sekolah, maka semakin baik pula komitmen guru. Darmanto \& Muharto (2014) juga menyimpulkan adanya pengaruh langsung kepemimpinan terhadap komitmen organisasi.

Selain itu, penelitian Candra (2019) menegaskan bahwa komitmen guru ditentukan oleh gaya kepemimpinan, budaya sekolah, dan motivasi terhadap kinerjanya. Hasil penelitian ini secara parsial menunjukkan gaya kepemimpinan kepala sekolah berpengaruh signifikan terhadap kinerja guru, budaya sekolah berpengaruh signifikan terhadap kinerja guru, dan motivasi berpengaruh signifikan terhadap kinerja guru. Kinerja guru dalam menjalankan tugas pokok dan fungsi sebagai tenaga pendidikan dilandasi komitmen. Begitu juga Riyanta (2016) dalam penelitiannya menyimpulkan bahwa mengembangkan budaya mutu di sekolah melalui kepemimpinan transformasional dapat dilakukan bersama-sama oleh kepala sekolah, guru, dan staf yang ada di sekolah. Penanaman nilai-nilai budaya dan karakter terhadap warga sekolah khususnya guru dapat dilakukan melalui berbagai kegiatan rutin, spontan, keteladanan, pengondisian, kegiatan ekstrakurikuler, aktivitas pembelajaran di kelas, serta berkomunikasi dengan pihak orang tua/wali siswa.

\section{SIMPULAN}

Kepemimpinan kepala SMAN di Kota Sekayu berhubungan signifikan dengan komitmen guru dalam melaksanakan tugas. Pengaruh antara kedua variabel tersebut termasuk dalam kategori "tinggi”. Secara parsial, kepemimpinan kepala sekolah berpengaruh signifikan terhadap komitmen guru dalam melaksanakan tugas. Pengaruh anatara kedua variabel tersebut termasuk dalam kategori “tinggi”. Budaya organisasi di SMAN di Kota Sekayu berhubungan signifikan 
dengan komitmen guru dalam melaksanakan tugas. Pengaruh kedua variabel termasuk dalam kategori “tinggi”. Secara parsial, budaya organisasi sekolah berpengaruh signifikan terhadap komitmen guru dalam melaksanakan tugas.

Kepemimpinan kepala sekolah dan budaya organisasi berhubungan kuat dan signifikan dengan komitmen guru SMAN di Kota Sekayu dalam melaksanakan tugas. Kepemimpinan kepala sekolah dan budaya organisasi secara parsial dan simultan berpengaruh signifikan terhadap komitmen guru dalam melaksanakan tugas. Keadaan ini akan berdampak kepada pelaksanaan proses belajar di sekolah. Komitmen guru SMAN di Kota Sekayu masih dapat ditingkatkan dengan memperbaiki sektor-sektor pembelajaran yang belum diselenggarakan dengan baik. Kepala sekolah sebagai penggerak dan kunci keberhasilan di sekolah tidak cukup hanya menjalankan kepemimpinan dan mengandalkan budaya organisasi sekolah. Guru juga harus menguasai berbagai kompetensi yang dibutuhkan agar mereka mampu mengembangkan proses pembelajaran yang efektif.

\section{DAFTAR PUSTAKA}

Aminuddin, A. (2017). Pengaruh kepemimpinan kepala sekolah dan pengawasan pengawas sekolah terhadap kinerja guru dalam mewujudkan prestasi belajar pendidikan agama Islam. Jurnal Pendidikan. 11(1).

Candra, V. (2019). Pengaruh gaya kepemimpinan, budaya sekolah dan motivasi terhadap kinerja guru SMP swasta. Harmoni Sosial Jurnal Pendidikan IPS. Vol. 6 No. 11.

Colquitt, J.A., LePine, J.A., \& Wesson, M.J. (2009). Organizational behavior (improving performance and commitment in the workplace). New York: McGraw-Hill Higher Education.

Darmanto, \& Muharto, T. 2014. Perilaku organisasi. Tangerang: UT.

Ekosiswoyo, R. (2007). Kepemimpinan kepala sekolah yang efektif kunci pencapaian kualitas pendidikan. Jurnal Ilmu Pendidikan. 14(1), 76-82.

Flippo, E. B. (2012). Manajemen personalia (jilid 1). Jakarta: Erlangga.

Jannah, W. (2014). Komitmen guru dalam melaksanakan tugas di Sekolah Menengah Atas (SMA) kecamatan Rokan IV Koto. Jurnal Bahana Manajemen Pendidikan/Administrasi Pendidikan. 2(1), 789-831.

Jurman. (2014). Budaya organisasi dalam meningkatkan kinerja guru pada SMA negeri 1 Simeuleu Timur. Jurnal Ilmiah DIDAKTIKA. 14(2). 275-290.

Koestoero, P., \& Hadisucipto, A. (1998). Diagnosis dan pemecahan kesulitan belajar. Jakarta: Erlangga.

Kosim, M. (2017). Pengaruh kepemimpinan kepala sekolah terhadap kinerja guru untuk mewujudkan mutu pembelajaran. Jurnal Khazanah Akademia. 1(1).

Mathis, R.L., \& Jackson, J.H. (2011). Manajemen sumber daya manusia. Jakarta: Salemba Empat.

Mawaddah, M., Harapan, E., \& Kesumawati, N. (2020). Pengaruh kepemimpinan kepala sekolah dan sarana prasarana terhadap kepuasan kerja guru. Jurnal Manajemen, Kepemimpinan dan Supervisi Pendidikan (JMKSP). 6(1). 34 -43.

Muis, M.R., Jufrizen, J., \& Fahmi, M. (2018). Pengaruh budaya organisasi dan komitmen organisasi terhadap kinerja karyawan. Jurnal Ekonomi \& Ekonomi Syariah. 1(1), 9-25. 
Muslim, B., Harapan, E., \& Kesumawati, N. (2020). Kepemimpinan kepala sekolah dalam meningkatkan mutu pendidikan di SMA negeri 1 Inderalaya Selatan. Jurnal Intelektualita: Keislaman, Sosial dan Sains. 9(1). 149-158.

Nawawi, H. (2003). Manajemen sumber daya manusia untuk bisnis yang kompetitif, cetakan ke-7. Yogyakarta: Gadjah Mada Press.

Noe, R.A. et al. (2013). Manajemen sumber daya manusia (edisi keenam, buku 1 \& 2). Jakarta: Salemba Empat.

Peraturan Pemerintah Nomor 19 tahun 2005 tentang Standar Nasional Pendidikan.

Riyanta, T. (2016). Mengembangkan budaya mutu sekolah melalui kepemimpinan transformasional. Jurnal Manajemen Pendidikan. 12(1).

Rosdina. (2015). Perilaku kepemimpinan kepala sekolah dalam peningkatan kinerja guru pada SD Negeri 2 Lambheu kabupaten Aceh Besar. Jurnal Administrasi Pendidikan. 3(2).

Steers, R.M. (1991). Introduction to organizational behavior. Chicago: Scatt Foresman and Company.

Sugiyono. (2014). Metode penelitian pendekatan kuantitatif, kualitatif dan $R \& D$. Bandung: Alfabetha.

Suwarno, B. (1988). Pengantar aplikasi statistik dalam penelitian pendidikan. Bandung: PPs UPI Bandung

Syaiful, M. (2018). Komitmen guru dalam membentuk karakter siswa (studi multisitus di sekolah dasar islam Ihya Ulumuddin Nur Sufi'iyah dan sekolah dasar islam terpadu Ihsanul Amal). Tesis, Program Pascasarjana PGMI UIN Maulana Malik Ibrahim Malang, Tahun 2018.

Syamsul, H. (2017). Penerapan kepemimpinan kepala sekolah dalam meningkatkan kinerja guru pada jenjang Sekolah Menengah Pertama (SMP). Jurnal Idarah. 1(2).

Undang-undang Nomor 14 tahun 2005 tentang Guru dan Dosen.

Usman, M.U. (2017). Menjadi guru profesional, cetakan ke-29. Jakarta: Remaja Rosda Karya.

Yusuf, M.H. (2017). Pengembangan budaya organisasi dalam lembaga pendidikan. Jurnal Tarbawi. 14(1). 82-96.

Zahrana. (2017, November 22). Komitmen guru profesional. Retrieved from https://zahranaa.blogspot.com/2017/11/komitmen-guru-profesional_22.html?m=1 